\title{
PENGARUH MEDIA TERHADAP PERTUMBUHAN ISOLAT ACTINOMYCETES KODE AL35 SERTA OPTIMASI PRODUKSI METABOLIT ANTIBAKTERI BERDASARKAN WAKTU FERMENTASI DAN pH
}

\author{
INFLUENCE OF MEDIA TO ISOLATE GROWTH OF \\ ACTINOMYCETES CODE AL35 AND OPTIMIZATION OF \\ ANTIBACTERY METABOLITE PRODUCTION BASED ON \\ FERMENTATION TIME AND $\mathrm{pH}$
}

\author{
Sabrina Wulandari, Nanik Sulistyani \\ Fakultas Farmasi, Universitas Ahmad Dahlan \\ Email: naniksulistyani@gmail.com
}

\begin{abstract}
ABSTRAK
Actinomycetes merupakan salah satu mikroorganisme yang dapat menghasilkan metabolit sekunder antara lain antibiotik. Isolat Actinomycetes (AL35) telah diisolasi dari rizosfer tanaman padi. Tujuan dari penelitian ini adalah untuk mengetahui pengaruh media terhadap pertumbuhan isolat AL35 serta optimasi produksi metabolit antibakteri berdasarkan waktu fermentasi dan $\mathrm{pH}$. Media pertumbuhan yang digunakan adalah ISP 1, ISP 2, ISP 3, ISP 4, ISP 5 dan media SNA. Pertumbuhan isolat diamati berdasarkan miselium udara dan miselium vegetatif. Optimasi waktu produksi metabolit antibakteri dilakukan dengan waktu fermentasi hari ke 1 hingga hari ke 14. Optimasi dilakukan pada $\mathrm{pH}$ 5, 6, 7, 8, 9 dan 10 dengan waktu inkubasi 14 hari. Metode uji aktivitas antibakteri adalah metode sumuran. Parameter yang diukur adalah diameter zona hambat terhadap Staphylococcus aureus dan Eschericia coli di sekitar sumuran. Profil optimasi produksi metabolit sekunder berdasarkan $\mathrm{pH}$ dianalisis dengan membuat grafik hubungan antara $\mathrm{pH}$ dan diameter zona hambat, sedangkan berdasarkan waktu fermentasi, dibuat grafik hubungan antara waktu fermentasi dan zona hambat. Hasil penelitian menunjukkan bahwa isolat AL35 dapat tumbuh pada semua media yang digunakan dengan tingkat kesuburan yang berbeda-beda. Cairan kultur isolat AL35 dapat menghambat pertumbuhan S. aureus dan E. coli. Media yang menghasilkan tingkat kesuburan pertumbuhan isolat AL35 berturut-turut dari yang paling subur adalah media ISP4 lalu ISP5, SNA, ISP2, ISP3, dan ISP1. Waktu fermentasi untuk produksi metabolit antibakteri adalah hari ke 2, sedangkan $\mathrm{pH}$ optimal adalah $\mathrm{pH} 9$ berdasarkan aktivitas terhadap $S$. aureus dan pH 6 terhadap E. coli.
\end{abstract}

Kata kunci : Isolat Actinomycetes AL35, metabolit sekunder, media, waktu fermentasi, $\mathrm{pH}$ 


\section{ABSTRACT}

Actinomycetes is one of the microorganisms that can produce secondary metabolites such as antibiotics. An actinomycetes isolate (AL35) has been isolated from the rhizosphere of rice plants. The purpose of this study was to determine the effect of media on growth of AL35 isolate and optimization of antibacterial metabolite production based on fermentation time and $\mathrm{pH}$. The growth medium used were ISP 1, ISP 2, ISP 3, ISP 4, ISP 5 and SNA. Growth of isolates was observed based on aerial mycelium and vegetative mycelium. Optimization of antibacterial metabolite production time was done by fermentation time of day 1 until day 14. Optimization was carried out at pH 5, 6, 7, 8, 9 and 10 with incubation time of 14 days. The antibacterial activity test method used was the well diffussion method. The parameter measured was the inhibitory zone diameter against Staphylococcus aureus and Escherichia coli around the well. The optimization profile of secondary metabolite production based on $p H$ was analyzed using a graphic of the relation between $\mathrm{pH}$ and inhibitory zone diameter. Meanwhile based on the fermentation time, a graph of the relationship between fermentation time and inhibit zone was made. The results showed that AL35 isolate can grow on all media used with different fertility rates. The broth culture of AL35 isolates can inhibit the growth of S. aureus and E. coli. The medium that produced abundant growth rates of AL35 isolate from the most abundant were ISP4 media and ISP5, SNA, ISP2, ISP3, and ISP1. The fermentation time for antibacterial metabolite production was day 2, while the optimal pH was $\mathrm{pH} 9$ based on activity against $\mathrm{S}$. aureus and pH 6 against E. coli.

Keywords : Actinomycetes AL35, antibacterial metabolite, medium, fermentation time, $\mathrm{pH}$

\section{PENDAHULUAN}

Penyakit infeksi merupakan salah satu permasalahan dalam bidang kesehatan yang dari waktu ke waktu terus berkembang. Infeksi merupakan penyakit menular disebabkan oleh berbagai mikroorganisme seperti virus, bakteri, jamur, dan protozoa. Bakteri yang dapat menyebabkan infeksi antara lain (Isnaini, 2010) adalah Escherichia coli dan Staphylococcus aureus. Escherichia coli sering menyebabkan infeksi saluran kemih, diare dan penyakit lain. Salah satu penyembuhannya dengan antibiotik (Jawetz et al., 2001). Staphylococcus aureus merupakan contoh bakteri penyebab penyakit infeksi yang terutama dapat menimbulkan penyakit pada manusia.

Penyakit infeksi tersebut diatasi dengan antibiotik tetapi sering terkendala oleh adanya faktor resistensi bakteri terhadap antibiotik yang telah ada. Oleh 
sebab itu sangat diperlukan eksplorasi untuk mendapatkan mikroorganisme yang menghasilkan antibiotik dengan potensi lebih tinggi dalam mematikan penyebab penyakit, misalnya dari rizosfer (Rahayu, 2007).

Salah satu sumber potensial penghasil antibiotik adalah Actinomycetes. Actinomycetes termasuk bakteri yang berbentuk batang, gram positif, bersifat anaerobik atau fakultatif. Struktur Actinomycetes berupa filament lembut yang sering disebut hifa atau miselia, sebagaimana yang terdapat pada fungi, memiliki konidia pada hifa yang menegak. Actinomycetes merupakan bakteri yang bereproduksi dengan pembelahan sel, rentan terhadap penicilin tetapi tahan terhadap zat antifungi (Rollin and Joseph, 2000).

Apriliasari (2012) telah mengisolasi Actinomycetes dari tanah sawah padi yang berada di desa Pilahan Kidul, Rejowinangun, kecamatan Kotagede, Yogyakarta. Dari penelitian ini ditemukan 12 isolat yang memiliki aktivitas menghambat bakteri uji, salah satunya adalah isolat AL35. Untuk dapat dilakukan proses isolasi antibiotik secara efektif, maka perlu dilakukan berbagai optimasi kondisi fermentasi. Media, waktu dan $\mathrm{pH}$ fermentasi merupakan faktor penting yang harus dioptimasi. Produksi antibotik yang optimal dapat diperoleh dengan memperhatikan faktor waktu fermentasi, mengatur $\mathrm{pH}$ dan media pertumbuhan yang baik. $\mathrm{pH}$ berpengaruh terhadap aktivitas enzim yang memproduksi antibiotik, sedangkan waktu fermentasi dan media berpengaruh terhadap fase-fase pertumbuhan mikroorganisme (Sulistiyani, 2006). Media mengandung nutrisinutrisi yang akan mempengaruhi pertumbuhan isolat, dalam penelitian ini dilakukan optimasi media pertumbuhan dengan media ISP 1, ISP 2, ISP 3, ISP 4, ISP 5, dan SNA, media ini digunakan karena mempunyai perbedaan komposisi yang akan mempengaruhi pertumbuhan isolat tersebut. Hasil penelitian Apriliasari (2012) belum mencakup proses optimasi-optimasi tersebut. Oleh karena itu, penelitian ini dilakukan dengan tujuan mengetahui pengaruh media terhadap pertumbuhan isolat Actinomycetes kode AL35 serta optimasi produksi metabolit antibakteri berdasarkan waktu fermentasi dan $\mathrm{pH}$. 


\section{METODE PENELITIAN}

Alat-alat yang digunakan dalam penelitian ini meliputi peralatan gelas, cork borer, magnet stirer, autoclave, lampu spritus, ruangan LAF, blue tip, yellow tip, mikropipet, eppendorf, sentrifugasi, inkubator. Bahan utama dalam penelitian ini adalah isolat Actinomycetes kode AL35. Media cair untuk menumbuhkan isolat Actinomycetes adalah Starch Nitrat Broth (SNB). Mikroorganisme uji yang digunakan adalah Staphylococcus aureus ATCC 25923 dan Escherichia coli ATCC 25922. Media uji aktivitas antibakteri yang digunakan adalah BHI, Mueller Hinton, dan TSA. Bahan untuk media pertumbuhan adalah media ISP 1, ISP 2, ISP 3, ISP 4, ISP 5, dan media SNA.

Jalannya Penelitian

\section{A. Pembuatan Kultur Starter}

Pembuatan kultur starter dilakukan dengan memasukkan 1/4 plate isolat Actinomycetes kode AL35 ke dalam erlenmeyer yang berisi media SNB sebanyak $50 \mathrm{~mL}$ yang sudah disterilkan. Kultur diinkubasi pada suhu kamar selama 5 hari dengan pengadukan menggunakan magnetic stirer.

\section{B. Preparasi Kultur Uji}

Preparasi kultur uji dilakukan dengan memasukkan $10 \mathrm{~mL}$ starter ke dalam erlenmeyer yang berisi $100 \mathrm{~mL}$ media SNB yang sudah disterilkan. Selanjutnya diinkubasi selama 14 hari dengan pengadukan menggunakan magnetic stirer. Selama inkubasi, setiap hari diambil $1 \mathrm{~mL}$ kultur dan dimasukkan ke dalam tabung eppendorf dan diberi label, lalu disimpan dalam freezer. Dalam melakukan preparasi kultur uji ini dilakukan di ruangan LAF untuk meminimalkan terjadinya kontaminasi.

\section{Penyiapan Supernatan Cairan Kultur}

Hasil kultur uji yang diambil setiap hari selama 14 hari dikeluarkan dari freezer dan disimpan di kulkas sampai mencair. Setelah mencair kultur uji yang di simpan dalam eppendorf disentrifuse, setelah terpisah antara supernatant dengan endapan, supernatant dimasukkan dalam tabung eppendorf yang baru dan disimpan dalam freezer. Supernatan ini disebut sampel cairan kultur. 
D. Uji Aktivitas Cairan Kultur Isolat Actinomycetes Kode AL35 terhadap Bakteri Uji

Uji aktivitas cairan kultur isolat AL35 dilakukan terhadap Staphyloccus aureus dan Eschericia coli. Suspensi bakteri uji dioleskan di atas media Mueller Hinton Agar. Setelah itu, media dibuat sumuran menggunakan cork borer sesuai dengan pola yang sudah dibuat. Selanjutnya setiap lubang sumuran diisi dengan cairan kultur dari isolat kode AL35 kurang lebih $75 \mu \mathrm{L}$ lalu dimasukan ke dalam kulkas selama 2 jam, kemudian diinkubasi selama $18-24$ jam pada suhu $37^{\circ} \mathrm{C}$. Untuk melihat aktivitas dari cairan kultur isolat kode AL35 ditunjukkan dengan adanya zona jernih di sekitar sumuran.

E. Optimasi produksi metabolit antibakteri berdasarkan waktu fermentasi isolat Actinomycetes kode AL35

Optimasi produksi metabolit antibakteri berdasarkan waktu fermentasi dilakukan dengan cara menguji aktivitas antibakteri cairan kultur hari ke 1 hingga hari ke 14 terhadap S. aureus dan E. coli. Media Mueller Hinton diolesi dengan suspensi bakteri uji secara merata. Setelah itu media Mueller Hinton dibuat sumuran dengan menggunakan cork borer yang memiliki diameter $0,6 \mathrm{~cm}$. Selanjutnya, setiap lubang sumuran diisi dengan cairan kultur kurang lebih sebanyak $75 \mu \mathrm{L}$ sesuai dengan urutan harinya. Setelah semua sumuran diisi media dimasukkan ke dalam kulkas selama 2 jam, kemudian diinkubasi pada suhu $37^{\circ} \mathrm{C}$ selama 18-24 jam. Setelah 24 jam zona jernih di sekitar sumuran diamati dan diukur diameternya.

F. Optimasi Produksi Metabolit Antibakteri Berdasarkan pH

Optimasi dilakukan dengan cara memasukkan $2,5 \mathrm{~mL}$ starter yang berasal dari 1/4 plate isolat kode Actinomycetes AL35 ke dalam erlenmeyer yang berisi 25 $\mathrm{mL}$ media SNB yang telah disterilkan dan diatur $\mathrm{pH}$ nya, yaitu pada $\mathrm{pH} 5$ sampai 10, kemudian diinkubasi pada suhu kamar selama 5 hari dengan penggojogan. Media yang digunakan untuk uji ini adalah media Mueller Hinton yang sebelumnya sudah diolesi dengan suspensi bakteri yang akan diuji. Setelah itu media Mueller Hinton dibuat sumuran dengan menggunakan alat pembolong (cork borer) sebanyak 6 lubang sumuran. Kemudian setiap lubang sumuran diisi 
cairan kultur kurang lebih sebanyak $75 \mu \mathrm{L}$. Setelah itu media dimasukkan ke dalam kulkas selama 2 jam, kemudian diinkubasi pada suhu $37^{\circ} \mathrm{C}$ selama $18-24$ jam.

G. Uji Pengaruh Media terhadap Pertumbuhan Isolat Actinomycetes Kode AL35

Isolat Actinomycetes kode AL35 ditumbuhkan dengan cara digoreskan pada media ISP 1 (tryptone-yeast extract broth), ISP 2 (yeast extract-malt extract agar), ISP 3 (oatmeal agar), ISP 4 (Inorganic salts-starch agar), ISP 5 (Glycerolasparagine agar), dan SNA (Starch Nitrat Agar) selama 10 hari pada suhu kamar. Pengamatan warna miselium dilakukan dengan mengamati secara visual miselium udara dan miselium vegetatif, diamati dengan cara membalikkan petri untuk melihat pembentukan reverse side pigment. Pengamatan pigmen terlarut dilakukan dengan melihat adanya pembentukan warna terdifusi media.

\section{HASIL DAN PEMBAHASAN}

\section{A. Pembuatan Kultur Starter}

Kultur starter diinkubasi selama 5 hari dengan pengadukan menggunakan magnetic stirer. Terlihat perbedaan kultur pada hari ke tiga dan hari ke lima inkubasi, pada hari ke tiga media kultur masih terlihat bening dan jumlah pelet masih sedikit, sedangkan pada hari ke lima warna media berubah menjadi kecoklatan dan jumlah pelet semakin banyak.

\section{B. Penyiapan Supernatan Cairan Kultur}

Preparasi kultur uji dilakukan di ruang LAF (Laminai Air Flow) untuk mencegah terjadinya kontaminasi yang dapat menyebabkan mikroorganisme dalam kultur mati. Kultur starter dipindahkan ke dalam media baru bertujuan untuk peremajaan media, karena media yang baru mengandung nutrisi yang banyak, sehingga mendukung perkembangan bakteri lebih baik. Selanjutnya kultur diinkubasi selama 14 hari dan setiap hari kultur tersebut diambil $1 \mathrm{~mL}$ lalu disimpan dalam freezer. Warna kultur selama proses inkubasi mengalami perubahan, yaitu dari warna coklat muda sampai coklat tua dan jumlah pelet yang semakin banyak sampai inkubasi hari ke-14, keadaan ini membuktikan bahwa Actinomycetes mengeluarkan pigmen warna yang mampu berdifusi ke dalam media (Ambarwati \& Trisnawati, 2009). 
C. Uji Aktivitas Cairan Kultur Isolat Actinomycetes Kode AL35 terhadap Mikroorganisme

Tujuan dilakukan uji aktivitas cairan kultur isolat Actinomycetes AL35 adalah untuk mengetahui aktivitas dari cairan kultur terhadap pertumbuhan Staphylococcus aureus dan Eschericia coli. Uji aktivitas cairan kultur isolat Actinomycetes kode AL35 terhadap Staphylococcus aureus memiliki diameter zona hambat sebesar $26,5 \mathrm{~mm}$ (termasuk lubang sumuran), sedangkan uji pada Eschericia coli diameter zona hambat sebesar 20,75 mm (termasuk lubang sumuran). Kedua diameter zona hambat tersebut masuk dalam kategori aktivitas penghambatan sangat kuat. Dari hasil tersebut dapat diambil kesimpulan bahwa isolat Actinomycetes kode AL35 dapat menghambat pertumbuhan dari Stahpylococcus aureus dan Eschericia coli.

D. Optimasi Waktu Produksi Metabolit Sekunder Isolat Actinomycetes Kode AL35

Optimasi waktu produksi metabolit sekunder dapat digunakan untuk menentukan kapan waktu yang tepat untuk memproduksi metabolit sekunder yang optimal sebagai penghasil antibiotik. Optimasi waktu produksi metabolit sekunder dapat ditentukan dengan membuat grafik hubungan antara waktu inkubasi (fermentasi) dengan diameter zona hambat.

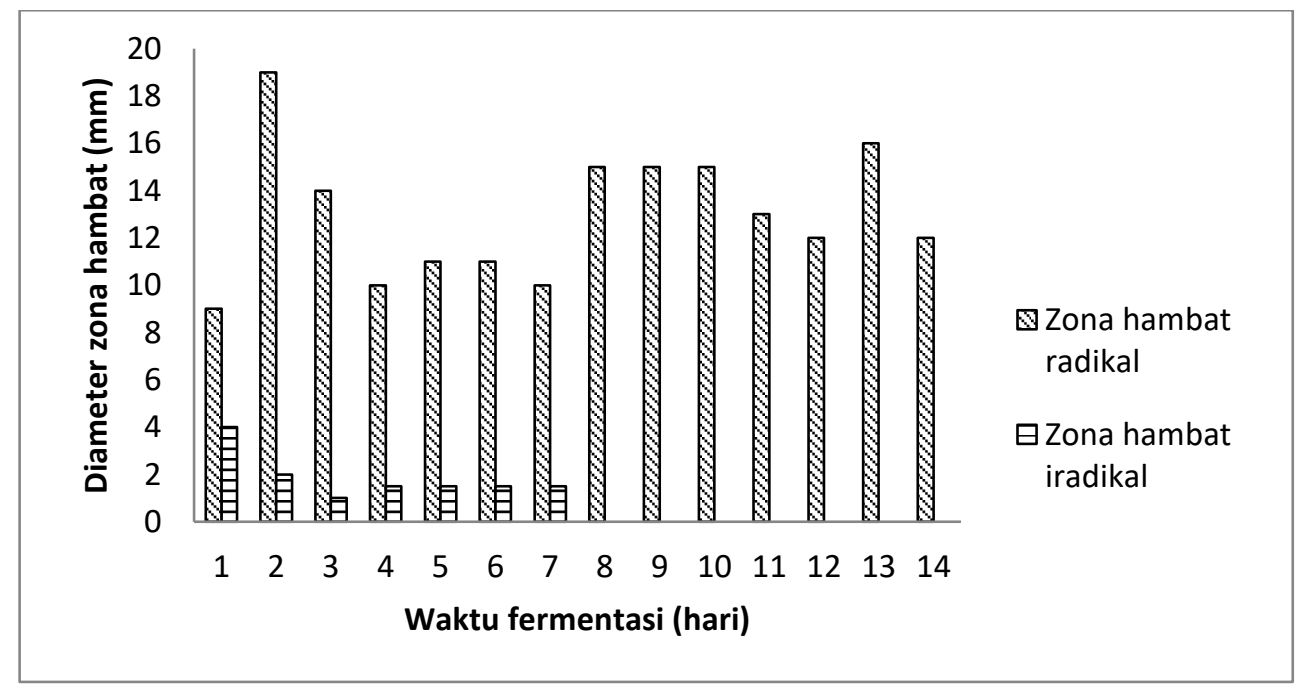

Gambar 1. Profil optimasi waktu produksi metabolit sekunder terhadap Staphylococcus aureus 
Hasil pengukuran zona hambat terhadap pertumbuhan Staphylococcus aureus menunjukkan bahwa hari ke-2 dan ke-13 merupakan waktu yang optimal untuk produksi metabolit sekunder sebagai antibiotik, karena menunjukkan zona hambatan yang paling besar daripada waktu inkubasi hari lainnya, pada hari ke-2 zona hambatan sebesar $19 \mathrm{~mm}$ dan pada hari ke-13 inkubasi, zona hambat sebesar $16 \mathrm{~mm}$. Profil optimasi waktu produksi metabolit sekunder terhadap Staphylococcus aureus dapat dilihat pada Gambar 1.

Pengukuran zona hambat pada pertumbuhan Escherichia coli juga sama, menunjukkan bahwa hari ke-2 inkubasi merupakan waktu yang optimal untuk memproduksi metabolit sekunder sebagai antibiotik dengan zona hambat sebesar $18 \mathrm{~mm}$. Hasil tersebut kemungkinan Actinomycetes kode AL35 memproduksi dua senyawa antibiotik yang berbeda, yang disintesis pada awal inkubasi dan pada akhir waktu inkubasi. Profil optimasi waktu produksi metabolit sekunder terhadap Eschericia coli dapat dilihat pada Gambar 2.

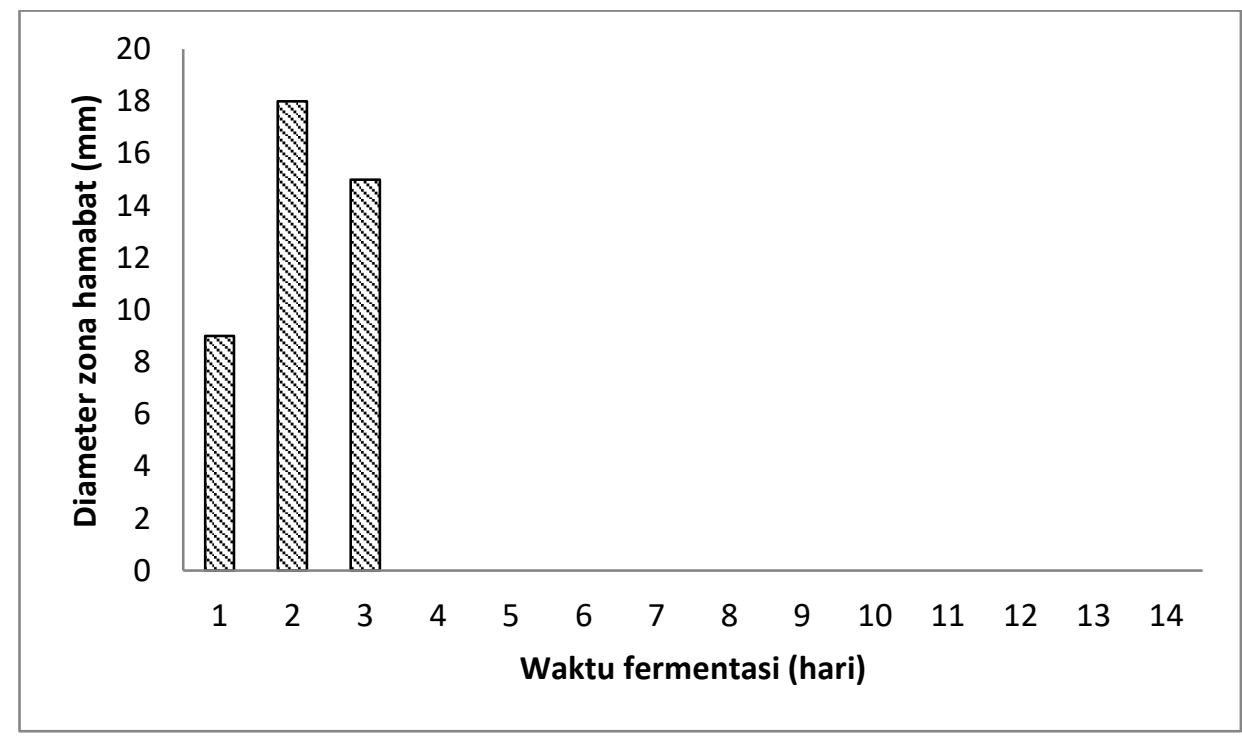

Gambar 2. Profil optimasi waktu produksi metabolit sekunder terhadap Eschericia coli

E. Optimasi pH Produksi Metabolit Sekunder Isolat Actinomycetes Kode AL35

Optimasi pH dapat digunakan untuk mengetahui pada kisaran $\mathrm{pH}$ manakah isolat Actinomycetes kode AL35 mampu tumbuh dan menghasilkan metabolit sekunder sebagai penghasil antibiotik. Banyak komponen yang mampu 
mempengaruhi pertumbuhan dan produksi senyawa antimikroba, salah satunya adalah $\mathrm{pH} . \mathrm{pH}$ berperan penting dalam reaksi enzimatis pembentukan metabolit. $\mathrm{pH}$ yang optimum dalam pertumbuhan memacu aktivitas produksi bioaktif. $\mathrm{pH}$ medium akan berpengaruh pada proses pembentukan dan kestabilan senyawa anti mikroba yang dihasilkan. Walaupun belum jelas meaknismenya, pada umumnya antibiotik akan terbentuk pada $\mathrm{pH}$ antara $7-8$, sedang pada $\mathrm{pH}$ yang lebih tinggi potensi antibiotik yang terbentuk akan terurai oleh suasana basa (Ulya, 2009).

Hasil uji menunjukkan bahwa pada pH 9 merupakan pH yang optimal untuk penghambatan terhadap Staphylococcus aureus, diameter zona hambat sebesar 18 mm. Profil optimasi $\mathrm{pH}$ terhadap Staphylococcus aureus dapat dilihat pada Gambar 3.

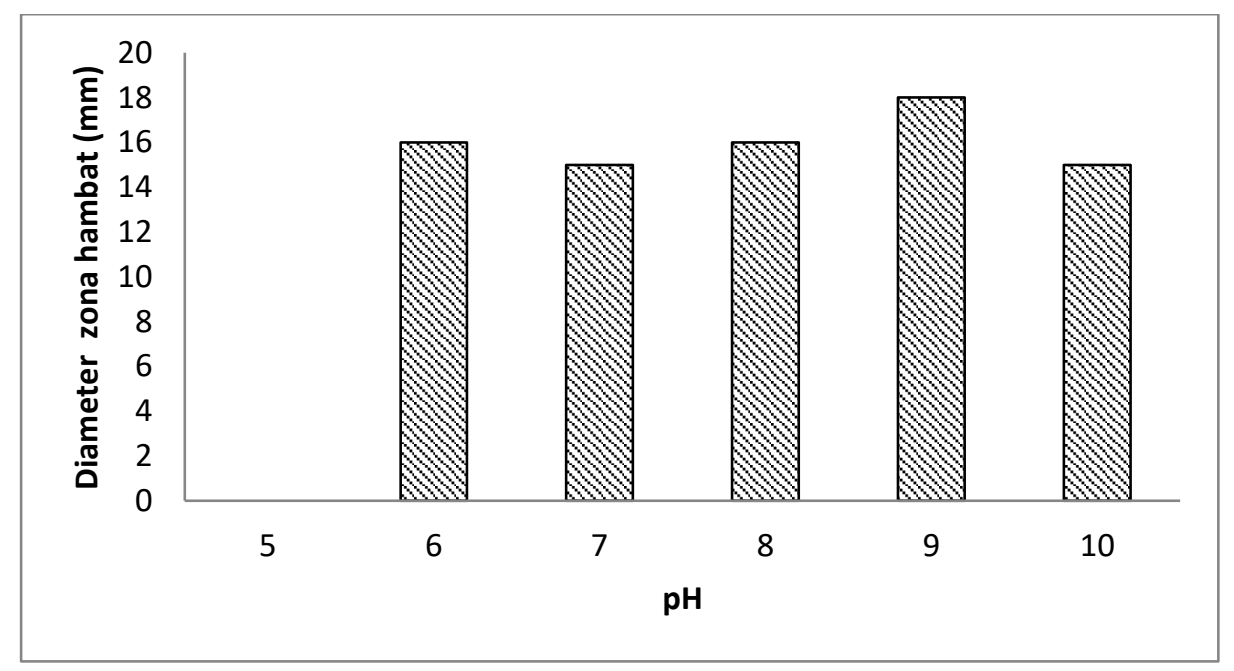

Gambar 3. Profil optimasi pH terhadap Staphylococcus aureus

Uji terhadap Eschericia coli menunjukkan bahwa pada pH 6 adalah pH optimum untuk penghambatan, diameter zona hambat sebesar $14 \mathrm{~mm}$. Profil optimasi pH terhadap Eschericia coli dapat dilihat pada Gambar 4. Perbedaan $\mathrm{pH}$ optimum tersebut kemungkinan terjadi karena setiap isolat menghasilkan beberapa anti mikroba yang mempunyai $\mathrm{pH}$ optimal berbeda satu dengan yang lain. Augustine et al. (2005) juga menyatakan bahwa perubahan pH pada media produksi merangsang senyawa baru yang berpengaruh pada produksi antibiotik. 


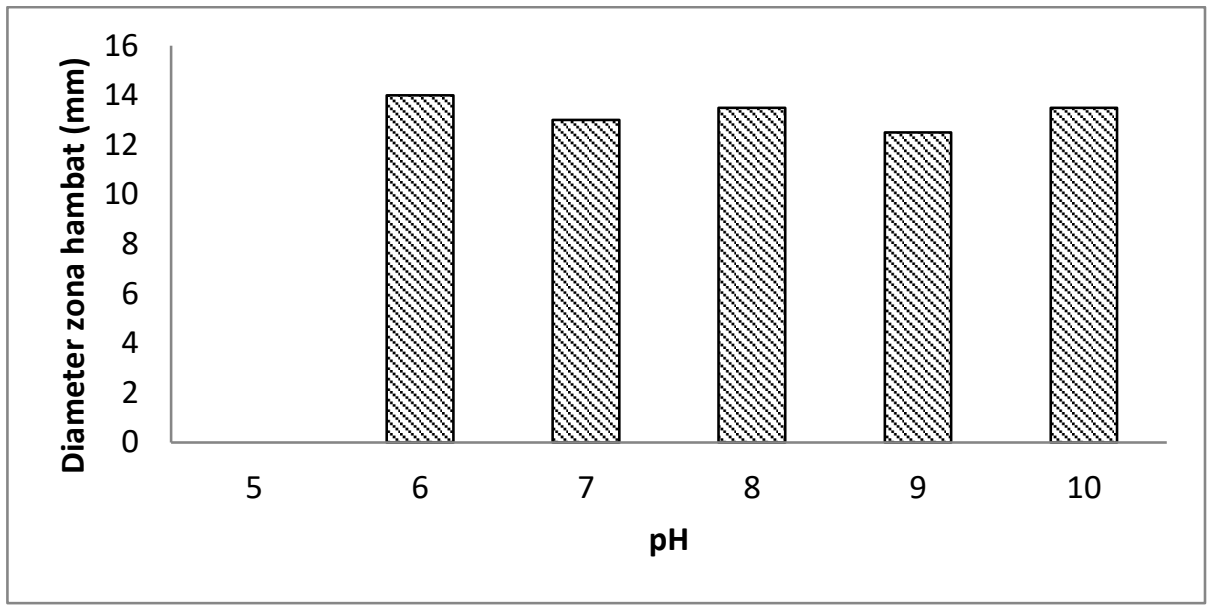

Gambar 4. Profil optimasi pH terhadap Eschericia coli

\section{F. Optimasi Media Pertumbuhan Isolat Actinomycetes kode AL35}

Optimasi media pertumbuhan ini bertujuan untuk mengetahui pengaruh media sebagai sumber nutrisi untuk pertumbuhan isolat. Media pertumbuhan yang baik merupakan media yang mampu menyediakan sumber karbon dan mineralmineral lain yang dibutuhkan dalam pertumbuhan maupun aktivitasnya (Todar, 2007). Dalam uji ini dilakukan optimasi pertumbuhan isolat pada beberapa media, yaitu media ISP 1, ISP 2, ISP 3, ISP 4, ISP 5, dan media SNA. Pengujian dilakukan dengan cara menggoreskan isolat murni dari isolat Actinomycetes kode AL35 pada beberapa media tersebut, dan selanjutnya diinkubasi pada suhu ruang selama kurang lebih selama 10 hari. Dalam kurun waktu 10 hari tersebut diamati pertumbuhan isolat meliputi miselium udara dan miselium vegetatifnya. Hasil optimasi media menunjukkan bahwa urutan pertumbuhan yang paling subur adalah pada media ISP 4 lalu ISP5, SNA, ISP2, ISP3, dan ISP1. Media ISP4 sebenarnya adalah media yang miskin akan nutrisi, banyak mengandung mineral dan pati sebagai sumber karbonnya. Pati pada media ISP 4 harus terlebih dahulu didegradasi menjadi senyawa yang lebih pendek rantainya dengan menghasilkan enzim amilase yang bertujuan untuk merombak pati menjadi karbon yang lebih tersedia.

Pati merupakan polimer kompleks terdiri atas $20 \%$ amilosa yang dapat larut dan $80 \%$ amilopektin yang sukar larut. Amilosa terpecah menjadi D-glukosa dan maltosa. Amilopektin dihidrolisis menjadi dekstrin, maltosa dan isomaltosa baru 
terbentuk D-glukosa. Dari penjelasan tersebut seharusnya pertumbuhan isolat tidak menunjukkan pertumbuhan yang subur karena proses panjang pemecahan pati menjadi sumber karbon yang sederhana, namun dari banyaknya komposisi mineral yang terkandung kemungkinan isolat menggunakan mineral-mineral tersebut untuk mensuplai energi yang digunakan untuk pertumbuhan dan isolat Actinomycetes kode AL35 mampu bertahan untuk memecah pati menjadi sumber karbon yang lebih sederhana yang selanjutnya digunakan untuk pertumbuhannya. Prescott et al. (1999) juga menyatakan bahwa mikroorganisme membutuhkan nutrisi untuk mendukung pertumbuhan selnya, nutrisi yang dibutuhkan yaitu karbon $(\mathrm{C})$, nitrogen $(\mathrm{N})$, fosfor $(\mathrm{P})$, sulfur $(\mathrm{S})$, kalium $(\mathrm{K})$, magnesium $(\mathrm{Mg})$, kalsiu $(\mathrm{Ca})$, natrium $(\mathrm{Na})$ dan besi $(\mathrm{Fe})$, sedangkan mikronutrien yang dibutuhkan yaitu tembaga $(\mathrm{Cu})$, mangan $(\mathrm{Mn})$, seng $(\mathrm{Zn})$, nikel $(\mathrm{Ni})$, molibdenum $(\mathrm{Mo})$, dan kobalt (Co). Menurut Stanbury dan Whitaker (1987) mineral memiliki peran penting dalam reaksi enzim, yaitu sebagai kofaktor pada proses metabolisme. Kombinasi campuran mineral juga berperan penting dalam regulasi elektrolit dan osmotik dalam sel dan dalam jumlah yang sedikit, mineral memiliki pengaruh terhadap pertumbuhan sel dan pembentukan produk. Dari pernyataan tersebut dapat disimpulkan bahwa mineral-mineral yang terkandung dalam media juga mampu untuk menyuplai energi untuk pertumbuhan isolat.

\section{KESIMPULAN}

Dari hasil penelitian dapat disimpulkan bahwa cairan kultur isolat Actinomycetes kode AL35 mampu menghambat pertumbuhan S. aureus dan E. coli. Pemanenan antibiotik yang optimal dapat dilakukan pada inkubasi hari ke-2 berdasarkan uji aktivitas terhadap $S$. aureus dan E. coli. $\mathrm{pH}$ optimum untuk penghambatan terhadap $S$. aureus adalah pada $\mathrm{pH}$ 9, dan untuk penghambatan terhadap E. coli adalah pada $\mathrm{pH}$ 6. Urutan media yang dapat menyuburkan pertumbuhan isolat Actinomycetes kode AL35 adalah media ISP4 lalu ISP5, SNA, ISP2, ISP3, dan ISP1. 


\section{DAFTAR PUSTAKA}

Ambarwati dan Trisnawati, A.G., 2009, Isolasi Actinomycetes dari Tanah Sawah Sebagai Penghasil Antibiotik, Jurnal Penelitian Sains dan Teknologi, 10(2): 101-111.

Apriliasari, 2012, Isolasi Actinomycetes Penghasil Antibiotik terhadap Escherichia coli dan Staphylococcus aureus dari Tanah Sawah Kotagede, Yogyakarta. Skripsi, Fakultas Farmasi Universitas Ahmad Dahlan, Yogyakarta.

Augustine, S.K., Bhavsar, S.P., and Kapadis, B.P., 2005, Production of growthdependent metabolite active agains dermatophytes by Streptomyces rochei Ak 39, Indian Journal of Medicine, 121: 164-170.

Isnaini, S.N., 2010, Isolasi Rare Actinomycetes dari Pasir Pantai Depok Daerah Istimewa Yogyakarta yang Berpotensi Antibiotik terhadap Propionibacterium acne, Skripsi, Fakultas Farmasi Universitas Muhammadyah Surakarta.

Jawetz, E., Melnick, J.L., Adelberg, E.A., Brooks, G.F., Butel, J.S., dan Ornston, L.N., 2001, Mikrobiologi Kedokteran Edisi ke-22, diterjemahkan oleh Nugroho \& R.F.Maulany, Penerbit Buku Kedokteran EGC, Jakarta.

Prescott, L.M., Harley, J.P., and Klein, D.A., 1999, Microbiology, New York: Mc Graw Hill.

Rahayu, T., 2007, Streptomyces Sebagai Sumber Antibiotik Baru di Indonesi, Prosiding Seminar Nasional Biologi, http://jurnal.fkip.uns.ac.id/index.php/prosbio/article/view/991/644, diakses tanggal 18 April 2013.

Rollin, D.M. dan Joseph, S.W., 2000, Actinomycetes Summary, http://www.life.umd.edu/classroom/bsci424/PathogenDescriptions/Actino mycetes.htm, diakses : Jumat, 31 Mei 2013.

Stanbury, P.F. and Whitaker, A., 1987, Priciples of Fermentation Technology. New York: Pergamon Press.

Sulistiyani, T.R., 2006, Isolasi dan Karakterisasi Antibiotik dari Isolat Actinomycetes Tanah Pulau Timor Bagian Barat (NTT), Skripsi, Fakultas Matematika dan Ilmu Pengetahuan Alam Institut Pertanian Bogor.

Todar, K., 2007, Nutrion and Growth of Bacteria in Todar's Online Textbook of Bacteriology, Wisconsin: University Winconsin-Madison Departement of Bacteriology. 
Ulya, J., 2009, Kemampuan Penghambatan Streptomyces spp. Terhadap Mikroba Patogen Tular Tanah pada Beberapa Kondisi Pertumbuhan : Jenis Media, Waktu Produksi, pH, dan Suhu, Tesis, Sekolah Pasca Sarjana Institut Pertanian Bogor. 